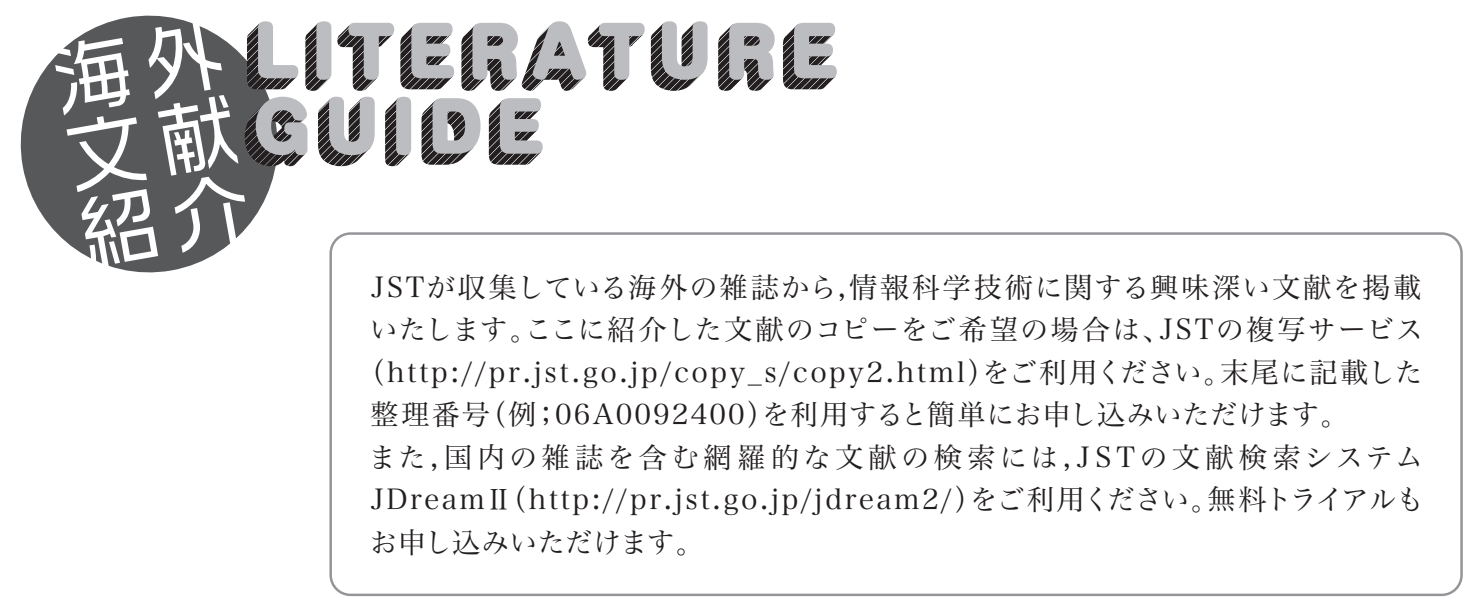

\section{電子ジャーナルと学術論文探索・閲読パターン の変化 \\ Electronic journals and changes in scholarly article seeking and reading patterns}

米国の大学その他に所属する自然科学, 技術, 医学, 社会科学の研究者を対象とする学術論文の 探索・閲読・利用に関する継続的な質問紙調査の 結果を報告した。この調查は1977年から始まり， 最近（2005年）の第5回調査では935名が回答した。 質問の多くは, 回答者が一番最近に読んだ論文に ついて詳細を尋ねたものである。1997年以来，1人 の研究者が 1 年あたり読む論文数は増加している が，1論文を読むのに要する時間は減少している。 現在では電子ジャーナルサイトからの論文入手が 主流であるが，精読はプリントアウトにより行わ れている。電子ジャーナルの利用により, より広 範囲の雑誌からより古い論文を得るようになった と回答されている。

TENOPIR Carol; EDWARDS Sheri; WU Lei (Univ. Tennessee, TN, USA); KING Donald W. (Univ. North Carolina, NC, USA), Aslib Proc (GBR) 200961 (1) 5-32, 09A0268090

\section{学生のディジタル情報捜索行動状況}

Student digital information-seeking behaviour in context

2つの大規模電子ジャーナルサイト（Blackwell
Synergy とOhioLINK）及び1つの電子ブックサイト （Oxford Scholarship Online）における利用ログデー 夕の分析から, 学生の実際の情報捜索行動につい て検討した。学生は, 同じサイトを利用する他の 学術コミュニティ構成員 (教授, 研究者, 専門家) とは明らかに異なる情報行動をとることを見出し た。たとえば，学生はオンラインセッション時間 が長く, セッションあたりの閲読ページ数が多い。 学部学生と大学院学生はともに, 図書館から学術 データベースへのリンクの最大の利用者である。

NICHOLAS David; HUNTINGTON Paul; ROWLANDS Ian; FIELDHOUSE Maggie (Univ. Coll. London, London, GBR); JAMALI Hamid R. (Tarbiat Moallem Univ., Tehran, IRN), J Doc (GBR) 200965 (1) 106132, 09A0213607

スペインの大学における科学論文共著の可視化 : 地域化から国際化へ

Visualization of scientific co-authorship in Spanish universities: From regionalization to internationalization

Web of Scienceから得られたスペインの大学研究 者による2000-2004年の論文100,710件に基づいて, 完全計数法による共著デー夕を得た。このデータ に社会ネットワーク可視化手法を適用し，大学間 及び国際間の共同研究ネットワークを分析した。 スペイン国内の大学間共同研究は, 地理的近縁さ と行政的区画の影響を受けており，域内で密集し 
たサブネットワークが域間でつながった構造に なっている。国際共同研究は, 主にEC, 北米, ラ テンアメリカと行われている。可視化技術により 国際関係が明瞭に示された。

OLMEDA-GOMEZ Carlos; PERIANES-RODRIGUEZ Antonio; OVALLE-PERANDONES M Antonia (Carlos III Univ. Madrid, Madrid, ESP); GUERRERO-BOTE Vicente P. (Univ. Extremadura, Badajoz, ESP); DE MOYA ANEGON Felix (CSIC, Madrid, ESP), Aslib Proc (GBR) 200961 (1) 83-100, 09A0268094

100人の最も多作な経済学者のために定義され検 証されたMatthew効果

The Matthew effect defined and tested for the 100 most prolific economists

Matthew効果を，頻繁に引用される論文または 著者はより頻繁に引用され，過剩な引用数は品質 の差によって説明されることはできないと定義す る。100人の最も多作な（107論文以上）経済学者 をIDEAS / RePEcから2007年5月に確認し, これ ら100人の論文と引用のデータはISI Web of Science からダウンロードした。論文への引用が論文への 以前の引用数によって影響されるかどうか（著者 内Matthew効果）及び著者への引用が著者への以 前の引用数によって影響されるかどうか（著者間 Matthew効果）をテストした。著者内Matthew効果 は，データセットにおける殆どの経済学者が保持 していた。また，過去に多数引用された経済学者 は不釣り合いな数の新しい引用を引き寄せていて 著者間Matthew効果が認められた。頻繁に引用さ れる論文はより頻繁に引用される，そして，頻繁 に引用される著者はより頻繁に引用される。2つの Matthew効果はお互いに増強し合う。著名な著者に よる著名な論文は最も引用される。Matthew効果は 現実のデータの中に見いだすことができる。

TOL Richard S. J. (Economic and Social Res. Inst., Dublin, IRL), J Am Soc Inf Sci Technol (USA) 2009 60 (2) 420-426, 09A0200194

RousseauとYeによる「動的hタイプ指数の提案」 に対する幾つかのコメント

Some comments on "a proposal for a dynamic h-type index" by Rousseau and Ye

Hirsh（2005）は，h指数を最初に公式化した論
文で, 特定著者の論文の引用は時間とともに線形 に増加するとした。Burrell (2007a，2007b）や Hirsh（2007）は, h指数に関連する引用の近似的 な線形増加を支持した。Rousseau \& Ye（2008）は， 2001-2007年間のRousseau自身のh指数, rational h指数 (Ruane \& Tol，2008)，R-指数 (Jin et al., 2007）による動的hタイプ指数を主張した。これら の指数の成長が（近似的に）線形であると考える 余地はなかった。Rousseau \& Ye（2008）が主張し たh夕イプ指標の瞬間的変化アプローチは実際的に は問題があることを示唆した。Rousseauのh夕イプ 指数データが示唆した幾つかの興味深い, 恐らく 重要な3つの課題について考察した。Hirsh（2005, 2007) やBurrell (2007a) によって主張された通り, h指数の進展のための線形形式は一般的に「典型的 なシナリオ」と見なすべきで，これから逸脱する ことは, Burrell (2007b) によって示唆されたよう に, 単に曲線の当てはめではなく科学計量学的に 研究されるべきである。

BURRELL Quentin L. (Isle of Man International Business School, Isle of Man, GBR), J Am Soc Inf Sci Technol (USA) 200960 (2) 418-419, 09A0200193

h指数の成長シミュレーション

Simulating growth of the h-index

直観的にはh指数は凹形に増加すると推測されて いるが，この推測（凹形増加）は実験的観察（線 形増加）と一致しない。引用モデルと論文モデル におけるh指数の進展の数值シミュレーションに よって凹形増加と線形増加の問題を検討した。 検討では通時的累積アプローチ（5夕イプ（Lin＆ Rousseau，2008））の場合のh指数の進展に注目し た。引用モデル「ファミリー」の決定論的ピーク モデルにおいて, パラメータの引用数のピーク時

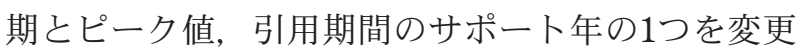
し, 他を固定した場合のh指数成長曲線への影響を

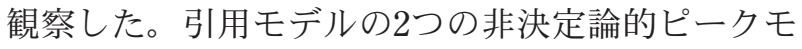
デルにおけるパラメータのピーク時期, サポート 年, 最小ピーク值, べき乗則指数, 引用数減少部 分の傾斜について, 第1モデル（サポート年固定） 及び第2モデル（傾斜固定）の場合にパラメータの 1つを変更し他を固定した場合のh指数成長曲線へ の影響を観察した。論文モデルでは，年間の論文 数が一定の場合と極めて小数の増加の場合の $\mathrm{h}$ 指数 成長曲線を検討した。多くの場合, シミュレーショ 
ンにおいてh指数は期間内（サポート年）に線形に 成長した。時にS字形が起きるが, 凹形増加は極め て稀であった。引用数に肯定的に影響したすべて の要因は, 同時に肯定的に成長曲線の速度と線形 性に影響した。

GUNS Raf (Univ. Antwerp, Antwerpen, BEL); ROUSSEAU Ronald (KHBO, Oostende, BEL), $J$ Am Soc Inf Sci Technol (USA) 200960 (2) 410-417, 09A0200192

\section{ISI主題カテゴリに基づいた科学のグローバル マップ}

A global map of science based on the ISI subject categories

ISI（科学情報研究所）のSCI（科学引用索引）に おける雑誌の主題カテゴリを用い, JCR（雑誌引用 レポート）による集合雑誌-雑誌引用の非対称（引 用と被引用）マトリックスを用いた科学のマッピ ングについて報告した。2006年JCRのCD-ROM版か らデー夕を取り込み, 因子分析を適用して14因子 を決定した。引用次元における14因子に関する 172 カテゴリ（引用）と175カテゴリ（被引用）の因子 負荷量の結果を専門領域について解釈した。172力 テゴリのうち154 (89\%) が引用と被引用のプロジェ クションの両方で同じ因子に分類された。171主題 カテゴリのマップと14因子グループの中の引用関 係を表現するマップを示した。主題カテゴリマッ プにおいて伝統的専門領域（例えば物理学や化学） は因子によって表現され, 数学や工学の応用分野 (例えば化学工学) は専門領域の分類の範囲には入 らないで, トピック（例えば化学）を表現する因 子に位置していた。引用次元における 14 グループ のマップは, 14グループの中の引用関係を的確に 表現した。ISI主題カテゴリに基づいた因子分析は, 科学の主要な構造を明確に表現し, 総合的で信頼 性のある科学のマッピングを可能にした。

LEYDESDORFF Loet (Univ. Amsterdam, Amsterdam, NLD); RAFOLS Ismael (Univ. Sussex, East Sussex, GBR), J Am Soc Inf Sci Technol (USA) 200960 (2) 348-362, 09A0200187
原共引用ネットワークから科学専門領域を発見 するための新しいアプローチ

A new approach for detecting scientific specialties from raw cocitation networks

任意の共引用ネットワークにおける科学の専門 領域を, 自由パラメータやデータの前後処理なし に，同定するために用いられる新しいコミュニティ 発見法（Blondel et al., 2008）を評価した。Blondel の階層的なクラスタリングアプローチは専門領域 （コミュニティ）の間の結び付きを発見すると同時 に，幾つかのコミュニティに結び付くノード（ア クタ）を直接的に同定するアルゴリズムを持つ。 情報検索と計量書誌学の研究領域において被引用 数の多い著者それぞれ 12 人の引用ネットワークに ついてBlondelアルゴリズムをテストし, 結果を他 のコミュニティ発見アルゴリズムと比較した。コ ミュニティの構造の識別においてBlondelアルゴ リズムは優れた結果を示した。また, 物理学雑誌 （1905-1911）の最も引用された100人の著者の引用 ネットワークについてBlondelアルゴリズムをテス トし, アルゴリズムの階層の一次レベルで容易に 発見できるコミュニティを明示した。引用ネット ワークから発見された結果としてのコミュニティ は, 直観的に認識する専門領域と調和的に対応し ていた。

WALLACE Matthew L.; GINGRAS Yves (Univ. Quebec a Montreal, Quebec, CAN); DUHON Russell (Indiana Univ., IN, USA), J Am Soc Inf Sci Technol (USA) 200960 (2) 240-246, 09A0200179

\section{イネ科植物のためのゲノム的および遺伝的デー タベース資源}

Genomic and genetic database resources for the grasses

厳密に言えば生物学的データベースはWebサイ トではないが, データベース内に貯蔵されている データにアクセスするために研究者が用いる接点 はほとんどがWebサイトである。過去10年間, 大 量処理技術の到来によって, シーケンシング, マッ ピング, 発現実験から生成するデー夕量が適切に データベースに保存できるようになった。さらに, 生物に関するデータベースにおけるデータ間の関 係は複雑であり，広範なデータにアクセスする 最善の方法はWebに基づくインターフェースであ 
る。理想的なイネ科植物のデータベースは, 他の 注釈や遺伝子に由来する生物学的特徵のフレーム ワークを提供するためにゲノム配列を利用してお り，大量処理のシーケンシングやバイオ情報の利 用と共に, ゲノム配列は遺伝子のエキソン, イン トロンおよび非翻訳領域構造などを描写する遺伝 子モデルによる注釈が可能になった。このUpdate ではゲノム配列，注釈および遺伝資源データを含 むイネ科植物のデータベースに関するレビューを 行い, これらデータベースの完全性, 品質および 相関性について考察した。

CHILDS Kevin L. (Michigan State Univ., MI, USA), Plant Physiol (USA) 2009149 (1) 132-136, 09A0223019

\section{オープンアクセス雑誌への誘引カ : 生物学分野 における計量書誌学的著者分析}

Attracted to open access journals: A bibliometric author analysis in the field of biology

開発途上国の著者は, 先進国の著者に比べて, 購読費がかからないオープンアクセス（OA）雑 誌を利用する傾向が高いという仮説の検証を試み た。生物学分野の 150 誌の 2006 年における発表論文 とそれに引用された論文における開発途上国著者 の比率を, 雑誌別に測定した。この比率と, 雑誌 がOAか否かの関係を，いくつかの制御変数を含め た線形重回帰分析により調べた。その結果，発表， 引用のいずれにおいても有意な関係は見られず, 仮説は支持されなかった。

FRANDSEN Tove Faber (Royal School of Library and Information Sci., Copenhagen, DNK), J Doc (GBR) 200965 (1) 58-82, 09A0213605

\section{HRGD：植物における潜在的雑種強勢関連遺伝}

子を発掘するためのデータベース

HRGD: A database for mining potential heterosisrelated genes in plants

雑種強勢関連遺伝子データベース（HRGD）を 設計, 公開した。このデータベースは主要農作物 間の雑種強勢に関連する比較トランスクリプトー ム研究情報を実用的デー夕発掘のために分析, 管 理する。また, 発育段階, 器官・組織, 機能等に 関する実験から得たイネゲノム，およびイネを含 む主要作物のコムギ，トウモロコシゲノム由来の
雑種親組織の 5,000 以上の示差発現遺伝子 (DEGs) に関する文献情報を含む。遺伝子配列，ゲノム構 造および機能的注釈の他, 経験的発現デー夕を含 む関連する遺伝子に注釈をつけた。リンクする多 くのデータベースを通して情報を可視化, 分析, 総合化できる。

SONG Shuhui; WANG Xuan; QU Hongzhu; WANG Weiwei; GE Xiaomeng; HU Songnian; LIU Guozhen; YU Jun (Beijing Inst. of Genomics, Chinese Acad. of Sci., Beijing, CHN); HUANG Yuefeng; LIANG Yanchun (Jilin Univ., Changchun, CHN); WEI Gang (Inst. of Genetics, Chinese Acad. of Sci., Beijing, CHN), Plant Mol Biol (NLD) 200969 (3) 255-260, 09A0184943

書誌計量を踏まえてのInternational Journal of Materials Researchの解剖

The anatomy of the International Journal of Materials Research in the light of bibliometry

標準計量書誌学法を用いてInternational Journal of Materials Research（IJMR）とその前身雑誌 Zeitschrift fuer Metallkunde（ZfM）を分析した。 ケミカルアブストラクサービス（CAS）と科学引用 索引 (SCI) の幅広く利用されている文献データベー 又間の学会誌の範囲の違いを調べた。もう一つの 前身誌Internationale Zeitschrift fuer Metallographie （IZfM）は，CASにはほとんど関連せず，SCIには 関連していなかった。原語としてのドイツ語及び 英語に関するZfM学会誌出版の時間発展は, 1969年 から言語の移行を明らかにした。1980年頃, ドイ ツ語及び英語で出版されたZfM論文の二つの匹敵す るアンサンブルは, ほとんど二つの因子で平均引 用率が異なる。IJMRとZfM論文の引用の分布, 未 引用論文の割合，もつともよく引用された論文の 時間発展を同等の学会誌と比較した。ZfM学会誌个 ンパクト・ファクター (JIF) は, Web of Science 主題範疇 “治金学と金属工学” の学会誌内で上位 に格付けされた。JIFの意義を考察し，デー夕を基 にした引用の適切な解釈のヒントを得た。

MARX Werner (Max Planck Inst. for Solid State Res., Stuttgart, DEU), Int J Mater Res (DEU) 2009100 (1) 11-23, 09A0181135 
協調Web検索：ロバスト性の解析

Collaborative web search: A robustness analysis

協調Web検索は，コミュニティ中の同じような 考えを持つ利用者の過去の検索履歴を使用して, 検索結果の品質を改善する。筆者らが提案した I-SPYシステムはこの一例であり, このシステムは まずGoogleなど通常の検索エンジンを利用し, 検 索結果を推せん出力の再ランキングに使用するメ 夕検索手法を使用している。しかし悪意利用者が 検索出力を操作し, 推せんを顕著に偏らせる問題 が生じている。本論文は, I-SPYシステムの悪意攻 撃に対するロバスト性を検討した。対象の結果ペー ジを，将来の検索時にランキングを上げることを 目的として, 特定コミュニティの質問空間に関連 させるように設計した攻撃モデルを示した。コミュ 二ティの均質性と, 協調検索のロバスト性との関 係も考察し, これがシステムのロバスト性に重要 な意味を持つコミュニティ特性であることを示し た。

O'MAHONY Michael P.; SMYTH Barry (Univ. Coll. Dublin, Dublin, IRL), Artif Intell Rev (NLD) 200728 (1) 69-86, 09A0100477
情報検索における学習単語重みづけ方式の公理 的比較：明確化と拡張

An axiomatic comparison of learned termweighting schemes in information retrieval:

Clarifications and extensions

単語重みづけは, 情報検索システムの多くにお ける文書ランキングの問題に不可欠である。機械 学習では単語重みづけ方式を, bag-of-words（単語 の集合）として学習する手法が一般化している。 本論文は，遺伝的プログラミング (GP) を使用す る，4種の文献に報告された単語重みづけ方式を述 ベた。また近年，良い単語重みづけ方式が順守す べき多数の公理（制約）を定義し，これを情報検 索に適用する手法が試みられている。この公理型 手法は, 純粋に自動化した学習手法へ適用する際 に便利である。本論文は，新しい公理を導入し， 標準のBM25単語重みづけ方式を修正することによ りその妥当性を検証した。標準BM25方式と, 上記 4 種のGPを使用して学習する単語重みづけ方式を 解析し，これら5方式の公理との一貫性を実験によ り評価し，4種のGP方式中の一つが公理との一貫性 が最善であることを示した。

CUMMINS Ronan; O'RIORDAN Colm (National Univ Ireland, Galway, IRL), Artif Intell Rev (NLD) 200728 (1) 51-68, 09A0100476 